University of Nebraska - Lincoln

DigitalCommons@University of Nebraska - Lincoln

Publications, Agencies and Staff of the U.S.

Department of Commerce

U.S. Department of Commerce

2003

\title{
Segregation of migration by feeding ground origin in North Atlantic humpback whales (Megaptera novaeangliae)
}

\author{
Peter T. Stevick \\ Sea Mammal Research Unit, Gatty Marine Laboratory, University of St Andrews, Fife KY16 8LB, Scotland, \\ U.K. \\ Judith Allen \\ College of the Atlantic \\ Martine Berube \\ University of Copenhagen \\ Phillip J. Clapham \\ Northeast Fisheries Science Center \\ Steven K. Katona \\ College of the Atlantic \\ See next page for additional authors \\ Follow this and additional works at: https://digitalcommons.unl.edu/usdeptcommercepub \\ Part of the Environmental Sciences Commons
}

Stevick, Peter T.; Allen, Judith; Berube, Martine; Clapham, Phillip J.; Katona, Steven K.; Larsen, Finn; Lien, Jon; Mattila, David K.; Palsbøll, Per J.; Robbins, Jooke; Sigurjonsson, Johann; Smith, Tim D.; Øien, Nils; and Hammond, Philip S., "Segregation of migration by feeding ground origin in North Atlantic humpback whales (Megaptera novaeangliae)" (2003). Publications, Agencies and Staff of the U.S. Department of Commerce. 164.

https://digitalcommons.unl.edu/usdeptcommercepub/164

This Article is brought to you for free and open access by the U.S. Department of Commerce at DigitalCommons@University of Nebraska - Lincoln. It has been accepted for inclusion in Publications, Agencies and Staff of the U.S. Department of Commerce by an authorized administrator of DigitalCommons@University of Nebraska - Lincoln. 


\section{Authors}

Peter T. Stevick, Judith Allen, Martine Berube, Phillip J. Clapham, Steven K. Katona, Finn Larsen, Jon Lien, David K. Mattila, Per J. Palsbøll, Jooke Robbins, Johann Sigurjonsson, Tim D. Smith, Nils Øien, and Philip S. Hammond 


\title{
Segregation of migration by feeding ground origin in North Atlantic humpback whales (Megaptera novaeangliae)
}

\author{
Peter T. Stevick ${ }^{1}$, Judith Allen ${ }^{2}$, Martine Bérubé ${ }^{3}$, Phillip J. Clapham ${ }^{4}$, Steven K. Katona ${ }^{2}$, Finn Larsen ${ }^{5}$, Jon Lien ${ }^{6}$ \\ David K. Mattila $^{7}$, Per J. Palsbøll ${ }^{3}$, Jooke Robbins ${ }^{7}$, Jóhann Sigurjónsson ${ }^{8}$, Tim D. Smith ${ }^{4}$, Nils Øien ${ }^{9}$ \\ and Philip S. Hammond ${ }^{1 *}$ \\ ${ }^{1}$ Sea Mammal Research Unit, Gatty Marine Laboratory, University of St Andrews, Fife KY16 8LB, Scotland, U.K. \\ ${ }^{2}$ College of the Atlantic, 105 Eden Street, Bar Harbor, ME 04609, U.S.A. \\ ${ }^{3}$ Department of Population Biology, University of Copenhagen, DK-2100 Copenhagen Ø, Denmark \\ ${ }^{4}$ Northeast Fisheries Science Center, 166 Water Street, Woods Hole, MA 02543-1026, U.S.A. \\ ${ }^{5}$ Greenland Institute for Natural Resources, P.O. Box 570, 3900 Nuuk, Greenland \\ ${ }^{6}$ Biopsychology Programme and Ocean Sciences Centre, Memorial University of Newfoundland, St Johns, Newfoundland A1C 5S7, Canada \\ ${ }^{7}$ Center for Coastal Studies, PO Box 1036, Provincetown, MA 02657, U.S.A. \\ ${ }^{8}$ Marine Research Institute, Skulagata 4, P.O. Box 1390, 121 Reykjavik, Iceland \\ ${ }^{9}$ Institute for Marine Research, P.O. Box 1870, Nordnes, 5024 Bergen, Norway
}

(Accepted 29 May 2002)

\begin{abstract}
Results from a large-scale, capture-recapture study of humpback whales Megaptera novaeangliae in the North Atlantic show that migration timing is influenced by feeding ground origin. No significant differences were observed in the number of individuals from any feeding area that were re-sighted in the common breeding area in the West Indies. However, there was a relationship between the proportion (logit transformed) of West Indies sightings and longitude $\left(r^{2}=0.97, F_{1,3}=98.27, P=0.0022\right)$ suggesting that individuals feeding farther to the east are less likely to winter in the West Indies. A relationship was also detected between sighting date in the West Indies and feeding area. Mean sighting dates in the West Indies for individuals identified in the Gulf of Maine and eastern Canada were significantly earlier than those for animals identified in Greenland, Iceland and Norway ( 9.97 days, $t_{179}=3.53$, $P=0.00054)$. There was also evidence for sexual segregation in migration; males were seen earlier on the breeding ground than were females ( 6.63 days, $\left.t_{105}=1.98, P=0.050\right)$. This pattern was consistently observed for animals from all feeding areas; a combined model showed a significant effect for both sex $\left(F_{1}=5.942, P=0.017\right)$ and feeding area $\left(F_{3}=4.756, P=0.0038\right)$. The temporal difference in occupancy of the West Indies between individuals from different feeding areas, coupled with sexual differences in migratory patterns, presents the possibility that there are reduced mating opportunities between individuals from different high latitude areas.
\end{abstract}

Key words: migration, segregation, breeding grounds, feeding grounds, Atlantic Ocean, Megaptera novaeangliae

\section{INTRODUCTION}

Extensive annual migration is a prominent feature in the lives of most mysticete cetaceans. Many species feed in productive high latitude waters, then migrate thousands of kilometres to low latitudes for calving and in some species also for mating. Even among mysticetes, humpback whales Megaptera novaeangliae are notable migrants with several instances of $8000 \mathrm{~km}$ migration reported (e.g. Stone, Florez-Gonzalez \& Katona, 1990; Darling et al., 1996; Stevick, Øien \& Mattila, 1999). However, details of migration patterns are often poorly

*All correspondence to: P. S. Hammond, Sea Mammal Research Unit, Gatty Marine Laboratory, University of St Andrews, Fife KY16 8LB, Scotland, U.K. E-mail: psh2@st-andrews.ac.uk known, as the frequently pelagic existence and wide range of mysticetes makes them difficult to observe. Further, cetacean populations may extend across entire ocean basins, so logistical and resource limitations have restricted most studies to a fraction of this range.

Individual humpback whales show a high degree of fidelity to sites within their summer feeding range in the North Atlantic; little exchange is observed between these areas. This leads to structuring of the population evident in movement patterns (Katona \& Beard, 1990), phenotypic characteristics (Allen et al., 1994) and mitochondrial genetic markers (Palsbøll, Clapham, Mattila et al., 1995). However, there is not necessarily a relationship between feeding areas and breeding areas and high-latitude origin is thought to have little influence on the breeding system (Clapham, 1996). 
Within the North Atlantic, feeding concentrations of humpback whales are found in areas of high productivity extending from the north-east coast of the U.S.A. to the Barents Sea (Katona \& Beard, 1990; Smith et al., 1999; Fig. 1). Individuals from all North Atlantic feeding aggregations are known to congregate on a common breeding area in the West Indies for mating and calving (Katona \& Beard, 1990; Stevick, Øien et al., 1999). Current evidence suggests that this behaviour leads to nearly random mating opportunities relative to feeding ground origin (Clapham, Mattila \& Palsbøll, 1993), and this is reflected in the genetic structure of the population (Larsen et al., 1996; Palsbøll, Clapham, Jørgensen et al., 1998; but see Valsecchi et al., 1997). However, significant deviation has been reported in the number of individuals from different feeding areas identified in the West Indies (Katona \& Beard, 1990). Further, non-random association has been shown between animals from some feeding aggregations and specific areas within the West Indies breeding ground (Whitehead \& Glass, 1985; Katona \& Beard, 1990).

There has been considerable uncertainty about the stock structure of humpback whales in the eastern North Atlantic. It has been suggested that eastern and western North Atlantic humpback whales constitute separate stocks, though the specific boundaries of the two stocks and the extent of overlap have been controversial (see reviews by Mitchell \& Reeves, 1983; Christensen, Haug $\&$ Øien, 1992). Humpback whales are known to occur in the Cape Verde Islands in winter (Hazevoet \& Wenzel, 2000), consistent with an eastern breeding area, though no re-sightings from this area have been confirmed. Genetic analysis of nuclear markers revealed a low but significant degree of heterogeneity between samples collected off Iceland and those collected in the western North Atlantic (Valsecchi et al., 1997). Recent findings that animals from Norwegian waters are sighted later in the West Indies season than the mean for other areas (Stevick, Øien et al., 1999) suggests that feeding ground origin may influence timing of occurrence in the West Indies.

Sighting records were analysed from the only largescale, systematic, capture-recapture study of humpback whales across an ocean basin to examine migration patterns in North Atlantic humpback whales. Presence on the breeding ground was examined as a function of feeding ground origin both overall and with respect to timing, and also as a function of sex.

\section{METHODS}

The data presented here were collected as part of the Years of the North Atlantic Humpback Whale project (YoNAH). Sampling for the YoNAH project was conducted during 1992 and 1993 in all of the major feeding areas and the West Indies breeding area (Smith et al., 1999). Standardized sampling protocols for locating groups of whales, systematically covering groups once located and maximizing the chances of successfully sampling each individual were used in all areas as described by
Smith et al. (1999). Individual animals were identified from photographs of natural markings on the ventral surface of the flukes (Katona et al., 1979). Because the quality of photographs can influence the ability of observers to identify re-sightings (Stevick, Palsbøll et al., 2001), the rate of re-sighting was calculated using only photographs of whole flukes of quality categories $3+$ or better as described by Friday et al. (2000). Skin biopsy samples were also collected for genetic analysis. Gender information was primarily obtained from these genetic analyses (Palsbøll, Vader et al., 1992; Bérubé \& Palsbøll, 1996a,b). Where individuals were identified as mothers with calves, but no biopsy samples were collected, these were classified as females. Details of field sampling protocol, survey effort, data collection, and laboratory methods are provided by Smith et al. (1999).

Great-circle distances were calculated using the formula presented by Bowditch (1977). Calculated migratory distances did not account for intervening land, as routes travelled are unknown, and in no instances did intervening land require a detour of $>$ c. $300 \mathrm{~km}$ from the direct transit. While little is known about arrival or residence times on the breeding grounds, few individuals were seen on multiple days, and the first date on which an individual was identified was used to indicate arrival time.

Individuals were assigned to 1 of 5 geographically distinct high-latitude feeding areas: the Gulf of Maine, Canada (comprising Newfoundland, Labrador and the Gulf of St Lawrence), West Greenland, Iceland and Norway (Fig. 1). As there is little information on movement patterns of individuals from the eastern North Atlantic, data from this region were treated in 4 different ways in preliminary analysis: (1) the pooled results from Iceland and Norway were treated as a single area; (2) samples from Iceland, the Barents Sea and near Jan Mayen were treated as 3 separate areas; (3) samples from the Jan Mayen area were grouped with Iceland because of geographic proximity and those from the Barents Sea were treated separately; (4) samples collected by the Icelandic and Norwegian field projects were considered as 2 areas. These different treatments usually had little influence on the results. Therefore, the geographically consistent grouping of Iceland with Jan Mayen was used in most analyses, while this group was sometimes further combined with the Barents Sea sample into an Eastern North Atlantic group.

To compare rates of exchange between the different feeding areas and the West Indies, observed re-sightings were compared with the number of re-sightings expected assuming random movement throughout the population. This is given as:

$$
\text { expected number of re-sightings }=\frac{f_{i} b}{\hat{N}}
$$

where $f_{i}=$ sample from feeding area $i, b=$ sample from the West Indies breeding area and $\hat{N}=$ estimated abundance.

Abundance of humpback whales in the North Atlantic was recently estimated as 10600 (95\% C.I. 8000-13 600) 

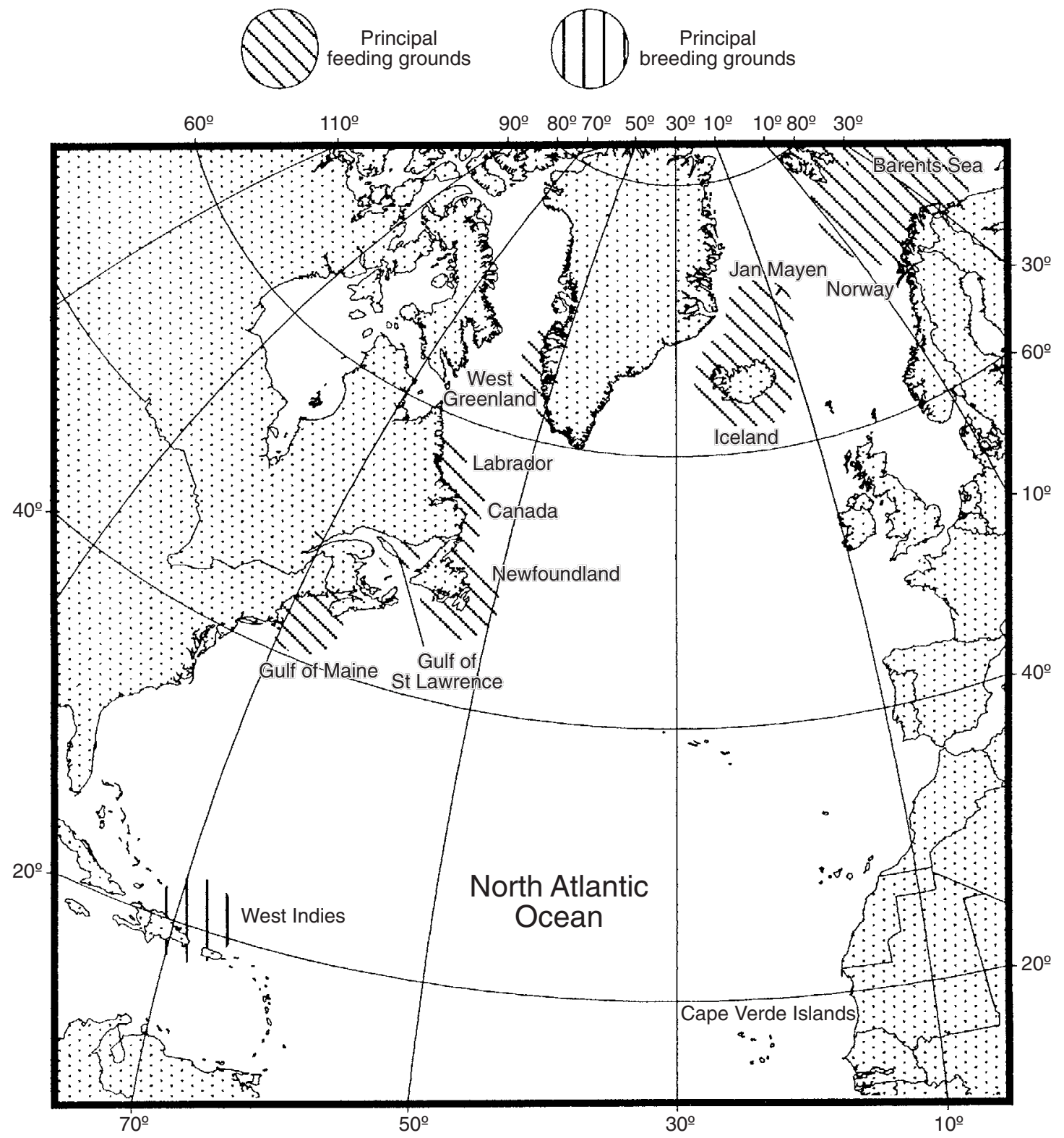

Fig. 1. The North Atlantic Ocean showing principal feeding and breeding habitats for humpback whales.

(Smith et al., 1999), and this estimate was used for these calculations.

\section{RESULTS}

A total of 1508 individual humpback whales was identified in the West Indies breeding area. Of these, 184 were resampled at high latitudes during the project of which 58 were identified as males and 49 as females. Of the individuals sighted in the West Indies, 1080 were identified from photographs of whole flukes of quality $3+$ or better, of which 153 were re-sighted in high latitudes from photographs of comparable quality (Table 1). Migratory distances observed ranged from 2300 to $8080 \mathrm{~km}$. Sampling in the West Indies extended from 15 January to 25 March 1992 and 19 January to 14 March 1993.

\section{Movement to the West Indies}

Individuals from all feeding areas were identified in the West Indies. The observed movements were not significantly different than expected, either overall $\left(\chi_{4}^{2}=\right.$ $3.95, P=0.41)$ or from any single feeding area. However, the observed numbers were greater than expected in the Gulf of Maine, Canada and Greenland and less than expected in Iceland and Norway. There was a logistic relationship between the proportion of individuals from each feeding area sighted in the West Indies and the longitude of the feeding area (Fig. $2 ; R^{2}=0.97, F_{1,3}=$ 98.27, $P=0.0022$ ).

West Indies sampling was conducted in four geographical areas: Silver Bank, Navidad Bank and Samana Bay off of the Dominican Republic and off the west coast of Puerto Rico. Individuals from the different feeding 
Table 1. The number of individual humpback whales identified in the five major North Atlantic feeding areas during 1992 and 1993. Re-sightings are presented from these feeding grounds to the West Indies breeding range and to sampling areas within the West Indies. Only sightings represented by quality $3+$ photographs or better are included. The sum of the sampling area re-sightings may exceed the regional totals because of individuals sighted in more than one area within the West Indies

\begin{tabular}{lllllll}
\hline & \multicolumn{5}{c}{ No. of West Indies re-sightings } \\
\cline { 2 - 7 } Region & $\begin{array}{l}\text { Individuals } \\
\text { identified }\end{array}$ & Total & Silver & Navidad & Samana & Puerto \\
Bayk & Bank & 4 & 0 \\
\hline Gulf of Maine & 242 & 28 & 24 & 0 & 17 & 4 \\
Eastern Canada & 863 & 90 & 74 & 2 & 4 & 2 \\
West Greenland & 170 & 19 & 14 & 2 & 1 & 1 \\
Iceland, Jan Mayen & 173 & 14 & 10 & 4 & 0 & 0 \\
Barents Sea & 53 & 2 & 1 & 1 & \\
\hline
\end{tabular}

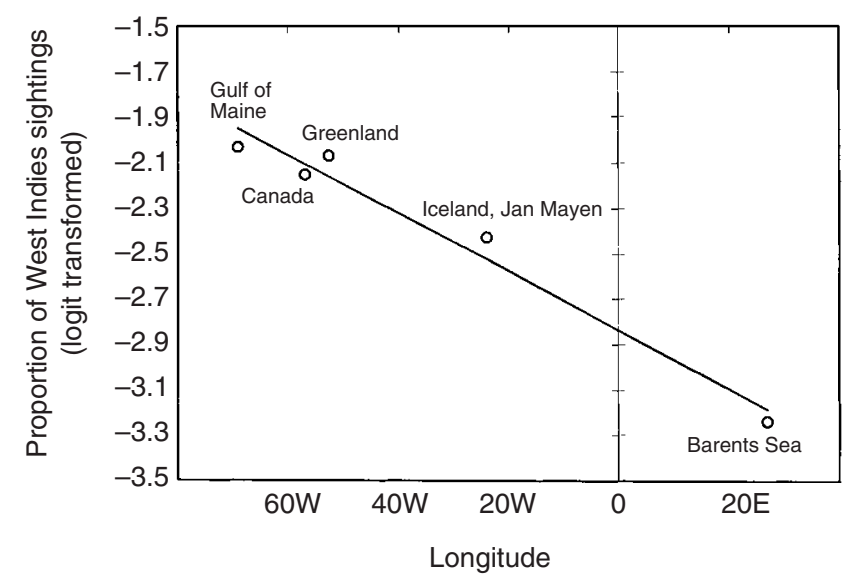

Fig. 2. The relationship between the proportion of re-sightings to the West Indies from each of the major high-latitude feeding grounds in the North Atlantic and the mean longitude of that area.

areas did not appear to be distributed as expected between these sampling areas given random mixing $\left(\chi_{12}^{2}=26.44\right.$, $P=0.0093$ ). However, these results must be treated with caution, as 13 of 20 cells had expected values of less than five.

\section{Timing}

Overall there was a positive relationship between breeding area sighting date and migratory distance (Fig. 3). Mean sighting dates in the West Indies for individuals from the U.S.A. and Canada (western group) were nearly identical (16 and 15 February, respectively), as were those for whales from Greenland, Iceland and Norway (eastern group, 26, 24 and 25 February, respectively). The mean sighting date in the West Indies of individuals from the western group was significantly earlier than that from the eastern group (9.97 days, $t_{179}=3.53, P=$ $0.00054)$. If animals from different feeding aggregations show preference for specific areas sampled within the West Indies, it is possible that some of the difference observed resulted from differences in sampling dates in these areas. However, the resulting difference in dates for sightings

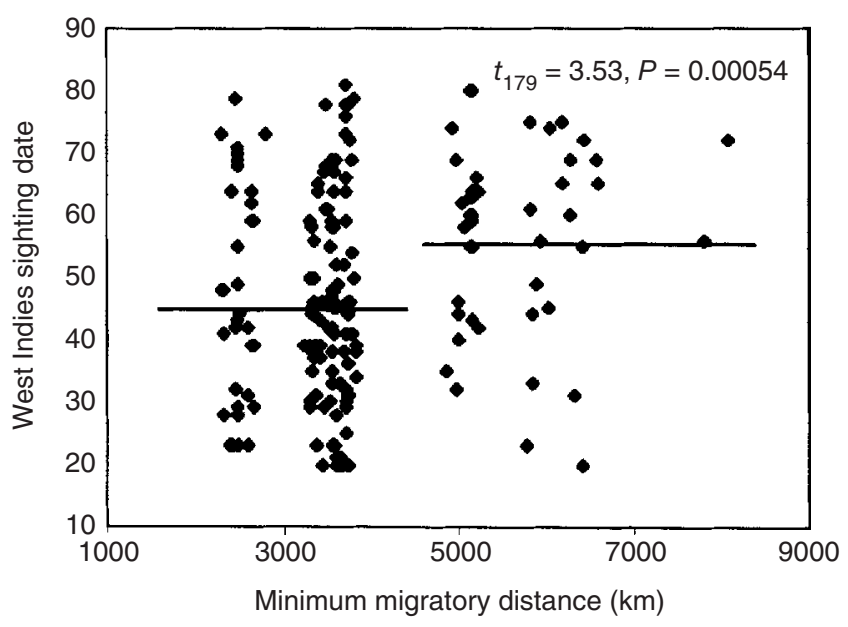

Fig. 3. The relationship between the minimum migratory transit distance for an individual and the first date of sighting in the West Indies for that individual. Mean sighting dates for the eastern and western groups are indicated. Dates are given as days of the year beginning January 1.

of eastern and western animals was similar when data were restricted to Silver Bank, the region of the West Indies from which over three-quarters of all individuals were identified, and the difference remained very highly significant (10.24 days, $P=0.00001)$.

Males were sighted earlier in the West Indies than were females (6.63 days, $\left.t_{105}=1.98, P=0.050\right)$. This pattern was consistently observed for animals from all feeding areas. To account for the differences in timing by feeding area, a two-way ANOVA was conducted. The interaction term was not significant and was excluded. A significant effect was shown for both sex $\left(F_{1}=5.942, P=0.017\right)$ and feeding area $\left(F_{3}=4.756, P=0.0038\right)$.

\section{DISCUSSION}

These results confirm that individuals from all feeding areas in the North Atlantic visit the West Indies in winter and do so at similar rates. Thus, these findings support the 
idea that individuals from throughout the North Atlantic use the West Indies region as a breeding and calving area. However, the change in proportion of West Indies sightings with longitude indicates that individuals from more easterly feeding areas are less likely to be observed in the West Indies.

Some humpback whales are known to winter outside the West Indies. Winter sightings are reported from the Cape Verde Islands for example (Hazevoet \& Wenzel, 2000). If whales using these other regions constitute a separate breeding group, and if these individuals primarily feed in the eastern regions of the North Atlantic as genetic results suggest (Valsecchi et al., 1997), then fewer animals from these eastern areas would travel to the West Indies. Alternatively, it has been suggested that not all humpback whales migrate or complete migration each year (Brown et al., 1995; Craig \& Herman, 1997). If this is true, then individuals with longer more costly migration may be less likely to be present on the breeding grounds in a given year, or may stay less time there, reducing the probability of them being identified. Given the temporal segregation identified here, the timing of sampling on the breeding grounds could influence the feeding ground origin of individuals in the sample from the West Indies, though previous studies have suggested that few humpback whales are sighted in the West Indies after the sampling period from this study (Whitehead, 1982). These explanations are not mutually exclusive and the data currently available do not allow us to distinguish between them.

\section{East is east and west is west}

Western and eastern humpbacks seem to follow different migratory schedules in the North Atlantic, with individuals from western regions arriving on average significantly earlier than whales from eastern regions. One potential explanation for this difference is the difference in transit distances to the West Indies; if migratory rates are similar, then individuals with longer transits will arrive later. Alternatively, if food resources are predictably available at different times in the different regions, departure dates may vary as a function of foraging strategy. There are currently few data available with which to evaluate either migratory travel rates or the timing of prey availability and its influence on timing of migratory departure.

While differences were observed in the degree to which individuals from the different feeding areas were sighted in the different regions within the West Indies, the ability to evaluate this difference quantitatively is limited by small sample size, and it may or may not reflect preferential associations between northern and southern areas. It may instead be related to the timing of sampling effort in the West Indies regions. On Navidad Bank, for example, where animals from the Gulf of Maine and Canada are under-represented and those from Iceland and Norway over-represented, only $30 \%$ of samples were collected before 20 February (early season). Similarly, the standardized deviates ((observed-expected)/expected $\left.{ }^{0.5}\right)$ for the western feeding group to the different West Indies areas showed a strong but non-significant relationship with the proportion of early season sampling in those areas $\left(r_{3}=0.71, \mathrm{NS}\right)$.

\section{Sexual segregation}

Segregation of migration by age, sex or reproductive class has been reported for several baleen whales (Lockyer \& Brown, 1981; Swartz, 1986; Dawbin, 1997). In humpback whales, sexual segregation has been noted in migration timing and in the frequency of sightings on the breeding grounds or migration routes (Brown et al., 1995; Dawbin, 1997).

Dawbin (1997) reported on the timing by sex and reproductive status of humpback whales from the catch records of Southern Hemisphere whaling stations located along migration routes. Comparisons of catch records with re-sighting records are confounded by the different levels of information available on sex and reproductive class for the two samples, and by different sampling biases. None the less, the gender differences in sighting dates from the West Indies observed in this study do not seem to be consistent with the migratory segregation identified by Dawbin (1997).

No overall difference in the catch dates of adult males and females is evident in the catch data from the southern hemisphere for individuals travelling north towards the breeding range (difference of 0.35 days). It is known that mothers with newborn calves are severely underrepresented in the photographic data as they rarely perform fluking dives. Excluding sightings of females with newborn calves from these results leads to the loss of four individuals from these data, and changes the mean sighting date for females by 0.21 days. In contrast, excluding females in late pregnancy from the catch results leads to females migrating on average 5.24 days earlier than males, nearly the reverse of the pattern identified here.

It is possible that individuals in the northern and southern hemispheres have developed different migratory schedules in relation to different selective pressures. Some evidence for inter-area differences in migratory segregation is found within the catch data. The catch data from several stations, notably Byron Bay, Moreton Island and Norfolk Island, show remarkably similar patterns to those identified here. However, Dawbin (1997) attributed these differences primarily to selection bias during whaling operations.

The use of common areas for breeding by whales from different feeding areas, high mobility within these breeding areas, the lack of evidence for preferential association in breeding groups between individuals from common feeding areas and the lack of nuclear genetic structure, have all suggested that mating opportunities in North Atlantic humpback whales are nearly random relative to high latitude origin. The results presented here show, however, that feeding ground origin does influence temporal presence of individuals in the West Indies. 
This temporal difference in occupancy patterns for the West Indies presents the possibility that there are reduced mating opportunities between individuals of different high latitude origins. The mean sighting date for males from the western group is nearly 3 weeks earlier than that of females from the eastern group (20.41 days, $t_{50}=3.30$, $P=0.0018)$. Further, it has recently been demonstrated that individual females are located in the West Indies on similar dates in subsequent years, and seem to have shorter residence time in the breeding grounds than do males (D. Mattila, pers. obs.). Thus the geographic origin of the males with which a female mates may be in part a function of her preferred timing in the breeding range. The extent to which these differences in timing influence mating opportunities depends upon the amount of time individuals spend in the breeding grounds, differences in residence times between males and females and also on the receptive period of females. Few data currently exist to help evaluate these parameters and thus to assess the extent to which mating opportunities are influenced by the timing difference.

Any degree of reproductive segregation between individuals of different high latitude origin might seem to be at odds with the high degree of genetic uniformity found in humpbacks from the North Atlantic. The segregation shown here is far from absolute, however. Only the relative number of individuals from the different high-latitude regions varies during the season. Very low rates of gene flow are required to maintain genetic homogeneity, so this relative segregation will not influence the genetic composition of the population.

Thus the sex, reproductive condition and high-latitude origin of animals using a breeding area will vary during the mating season. While the precise interplay of these factors may be difficult to unravel, they indicate that there is considerable complexity in the factors influencing the breeding system in humpback whales.

\section{Acknowledgements}

The large dataset examined here required the collective effort of many dozens of individuals who supplied crucial assistance in the field, the laboratory and with logistical and financial support. We are greatly indebted to them all. Funding for this analysis was provided by the W. E. Anderson trust and by the United States National Marine Fisheries Service under contract \#40ENNF800268 to PTS. Critical reading by Lisa Balance, Peter Best, Steve Buckland, Hal Whitehead, Ben Wilson and two anonymous reviewers improved the analysis and presentation.

\section{REFERENCES}

Allen, J. M., Rosenbaum, H. C., Katona, S. K., Clapham, P. J. \& Mattila, D. K. (1994). Regional and sexual differences in fluke pigmentation of humpback whales (Megaptera novaeangliae) from the North Atlantic Ocean. Can. J. Zool. 72: 274-279.
Bérubé, M. \& Palsbøll, P. J. (1996a). Identification of sex in cetaceans by multiplexing with three ZFX and ZFY specific primers. Mol. Ecol 5: 283-287.

Bérubé, M. \& Palsbøll, P. J. (1996b). Erratum of identification of sex in cetaceans by multiplexing with three ZFX and ZFY specific primers. Mol. Ecol. 5: 602.

Bowditch, N. (1977). The American practical navigator: an epitome of navigation 1, publication 9. Washington, DC: Defense Mapping Agency Hydrographic Center.

Brown, M. R., Corkeron, P. J., Hale, P. T., Schultz, K. W. \& Bryden, M. M. (1995). Evidence for a sex-segregated migration in the humpback whale (Megaptera novaeangliae). Proc. R. Soc. Lond. Ser. B Biol. Sci. 259: 229-234.

Christensen, I., Haug, T. \& Øien, N. (1992). Seasonal distribution, exploitation and present abundance of stocks of large baleen whales (Mysticeti) and sperm whales (Physeter macrocephalus) in Norwegian and adjacent waters. ICES (Int. Counc. Explor. Sea) J. Mar. Sci. 49: 341-355.

Clapham, P. J. (1996). The social and reproductive biology of humpback whales: an ecological perspective. Mammal Rev. 26: 27-49.

Clapham, P. J., Mattila, D. K. \& Palsbøll, P. J. (1993). High-latitudearea composition of humpback whale competitive groups in Samana Bay: further evidence for panmixis in the North Atlantic population. Can. J. Zool. 71: 1065-1066.

Craig, A. S. \& Herman, L. M. (1997). Sex differences in site fidelity and migration of humpback whales (Megaptera novaeangliae) to the Hawaiian Islands. Can. J. Zool. 75: 1923-1933.

Darling, J. D., Calambokidis, J., Balcomb, K. C., Bloedel, P., Flynn, K., Mochizuki, A., Mori, K., Sato, F., Suganuma, H. \& Yamaguchi, M. (1996). Movement of a humpback whale (Megaptera novaeangliae) from Japan to British Columbia and return. Mar. Mamm. Sci. 12: 281-287.

Dawbin, W. H. (1997). Temporal segregation of humpback whales during migration in southern hemisphere waters. Mem. Queensl. Mus. 42: 105-138.

Friday, N., Smith, T. D., Stevick, P. T. \& Allen, J. (2000). Measurement of photographic quality and animal distinctiveness for the photographic identification of humpback whales. Mar. Mamm. Sci. 16: 355-374.

Hazevoet, C. J. \& Wenzel, F. W. (2000). Whales and dolphins (Mammalia, cetacea) of the Cape Verde Islands, with special reference to the humpback whale Megaptera novaeangliae (Borowski, 1781). Contrib. Zool. 69: 197-211.

Katona, S. K., Baxter, B., Brazier, O., Kraus, S., Perkins, J. \& Whitehead, H. (1979). Identification of humpback whales by fluke photographs. In The behavior of marine animals 3. Cetacea: 33-44. Winn, H. E. \& Olla, B. L. (Eds). New York: Plenum Press.

Katona, S. K. \& Beard, J. A. (1990). Population size, migrations and feeding aggregations of the humpback whale (Megaptera novaeangliae) in the western North Atlantic Ocean. Rep. int. Whaling Comm. Spec. Issue 12: 295-305.

Larsen, A. H., Sigurjónsson, J., Øien, N., Vikingsson, G. \& Palsbøll, P. (1996). Population genetic analysis of nuclear and mitochondrial loci in skin biopsies collected from central and northeastern North Atlantic humpback whales (Megaptera novaeangliae): population identity and migratory destinations. Proc. R. Soc. Lond. Ser. B Biol. Sci. 263: 1611-1618.

Lockyer, C. H. \& Brown, S. G. (1981). The migration of whales. In Animal migration. Society of Experimental Biology, seminar series 13: 105-137. Aidley, D. J. (Ed.). Cambridge: Cambridge University Press.

Mitchell, E. \& Reeves, R. R. (1983). Catch history, abundance and present status of Northwest Atlantic humpback whales. Rep. int. Whaling Comm. Spec. Issue 5: 153-212.

Palsbøll, P. J., Clapham, P. J., Jørgensen, H., Larsen, F., Mattila, D. K., Sears, R. S. \& Vasquez, O. (1998). The value of parallel analysis of uni- and bi-parental inherited loci: the North Atlantic 
humpback whale. In Molecular tools for screening biodiversity: plants and animals: 426-430. Karp, A., Isaac, P. G. \& Ingram, D. S. (Eds). London: Chapman \& Hall.

Palsbøll, P. J., Clapham, P. J., Mattila, D. K., Larsen, F., Sears, R., Siegismund, H. R., Sigurjónsson, J., Vásquez, O. \& Arctander, P. (1995). Distribution of Mt DNA haplotypes in North Atlantic humpback whales: the influence of behavior on population structure. Mar. Ecol. Prog. Ser. 116: 1-10.

Palsbøll, P. J., Vader, A., Bakke, I. \& El-Gewely, M. R. (1992). Determination of gender in cetaceans by the polymerase chain reaction. Can. J. Zool. 70: 2166-2170.

Smith, T. D., Allen, J., Clapham, P. J., Hammond, P. S., Katona, S., Larsen, F., Lien, J., Mattila, D., Palsbøll, P. J., Sigurjónsson, J., Stevick, P. T. \& Øien, N. (1999). An ocean-basin-wide mark-recapture study of the North Atlantic humpback whale (Megaptera novaeangliae). Mar. Mamm. Sci. 15: 1-32.

Stevick, P. T., Øien, N. \& Mattila, D. K. (1999). Migratory destinations of humpback whales from Norwegian and adjacent waters: evidence for stock identity. J. Cetacean Res. Manage. 1: $147-152$.
Stevick, P. T., Palsbøll, P. J., Smith, T. D., Bravington, M. V. \& Hammond, P. S. (2001). Errors in identification using natural markings: rates, sources, and effects on capturerecapture estimates of abundance. Can. J. Fish. Aquat. Sci. 58: 1861-1870.

Stone, G. S., Florez-Gonzalez, L. \& Katona, S. (1990). Whale migration record. Nature (Lond.) 346: 705.

Swartz, S. L. (1986). Gray whale migratory, social and breeding behavior. Rep. int. Whaling Comm. Spec. Issue 8: 207-229.

Valsecchi, E., Palsbøll, P. J., Hale, P., Glockner-Ferrari, D. A., Ferrari, M., Clapham, P., Larsen, F., Mattila, D., Sears, R., Sigurjónsson, J., Brown, M., Corkeron, P. \& Amos, B. (1997). Microsatellite genetic distances between oceanic populations of the humpback whale (Megaptera novaeangliae). Mol. Biol. Evol. 14: 355-362.

Whitehead, H. (1982). Populations of humpback whales in the northwest Atlantic. Rep. int. Whaling Comm. 32: 345-353.

Whitehead, H. \& Glass, C. (1985). The significance of the Southeast Shoal of the Grand Bank to humpback whales and other cetacean species. Can. J. Zool. 63: 2617-2625. 